\title{
Has The United States
}

Enough Water?

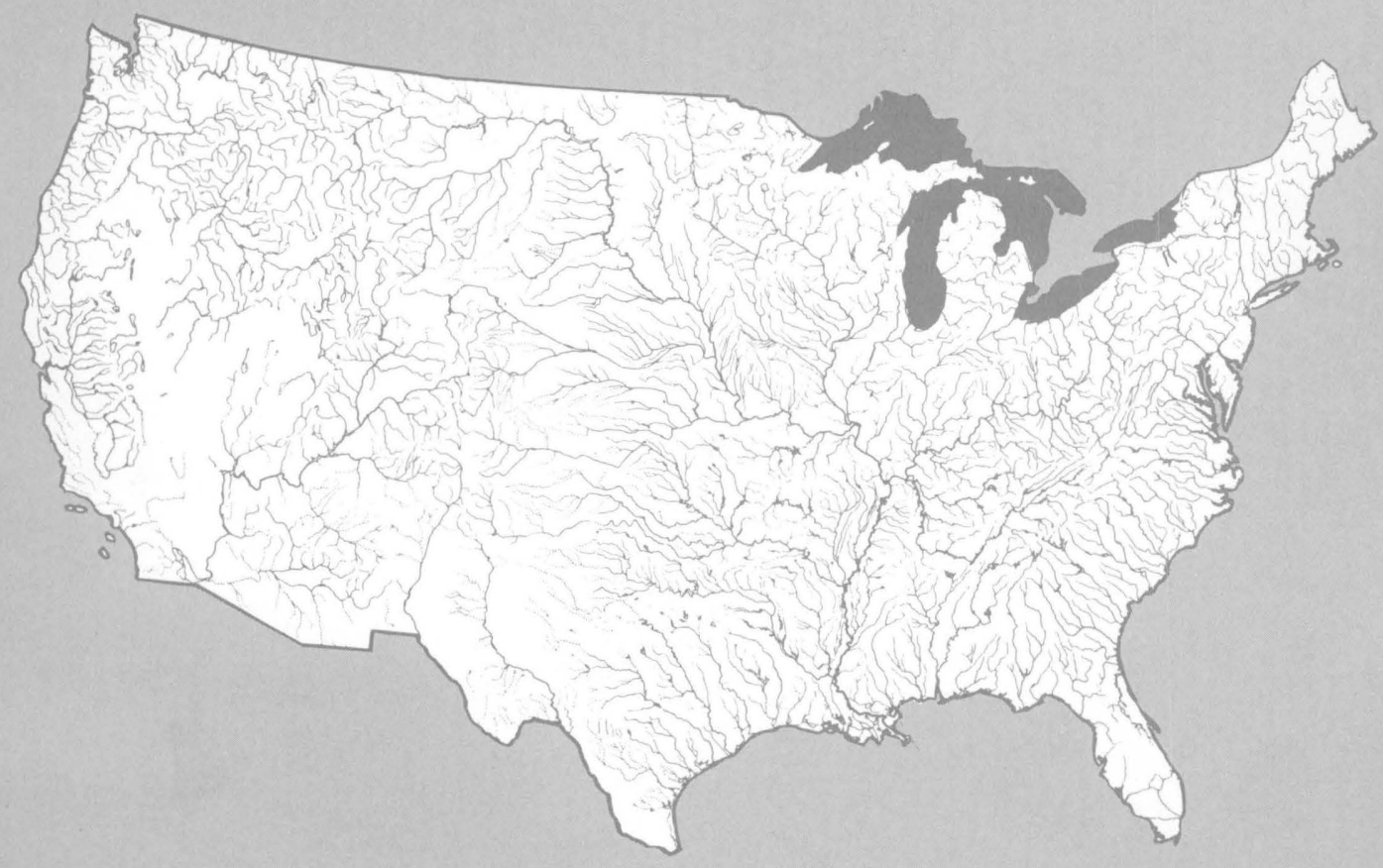




\section{Has the United States}

\section{Enough Water?}

By A. M PIPER

GEOLOGICAL SURVEY WATER-SUPPLY PAPER 1797

Estimates and projections (to the year 2000) of the water supplies and demands of the 19 major drainage basins

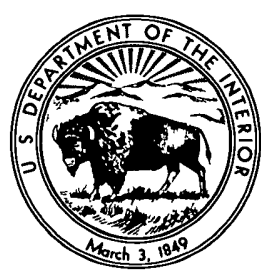


UNITED STATES DEPARTMENT OF THE INTERIOR

STEWART L. UDALL, Secretary

\section{GEOLOGICAL SURVEY}

Willam T. Pecora, Director

Library of Congress catalog-card No GS 65-342

First printing 1965

Second printing 1968 


\section{CONTENTS}

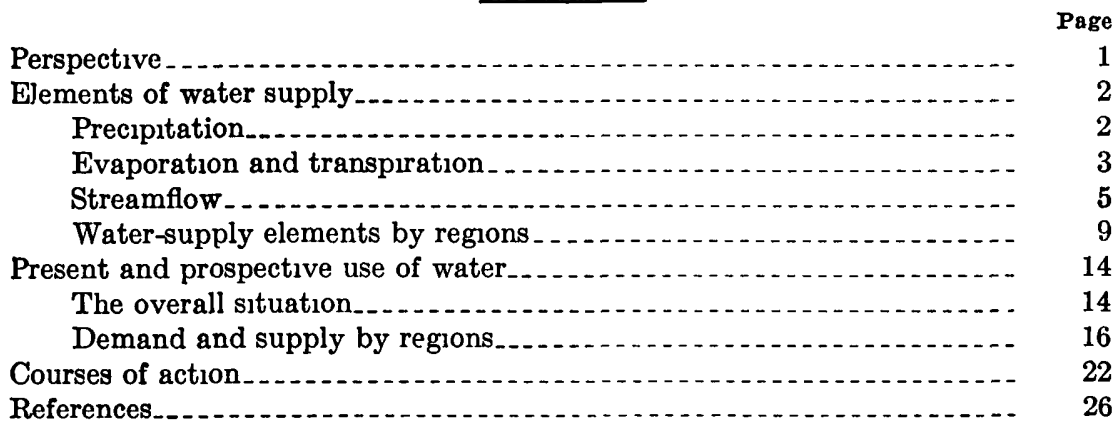

\section{ILLUSTRATIONS}

[Plates are in pocket]

Plate 1 Average precipitation in the conterminous United States and variation in precipitation at certain stations.

2 Water surplus and water deficiency in the conterminous United States.

3. Average runoff in the conterminous United States and flow characteristics of certain streams

Figdre 1. Natural and regulated streamflow, Merced River at Exchequer, Calif

2 Water-supply and water-use regions of the conterminous United States.

3 Projected water demand as of the year 2000

\section{TABLES}

TABLE 1. Approximate mean water-supply elements, by regions.........

2. Reservoirs and regulated lakes, existing and under construction as of 1954

3. Reservoirs required to assure flow equal to present median flow

4. Water withdrawn and water consumed, 1960 .

5. Estimated water withdrawn and water consumed, 1980 and 2000

6. Projected demand and supply of water as of the year 2000 , by types of demand and by regions

7. Summary of projected demand and supply of water as of the year 2000, by regions . .

8 Projected water demand as of the year 2000 . 


\title{
HAS THE UNITED STATES ENOUGH WATER?
}

\author{
By A. M. PIPER
}

\section{PERSPECTIVE}

The destiny of the Nation's water supply is currently a topic of frequent concern in the popular and quasi-technical press. Overly pessimistic writers imply or all but conclude that, within the foreseeable future, much of the United States will have dissipated its available water by consuming it or by grossly polluting it and that consequently industrial expansion must cease at one place or another, irrigated agriculture will wane or even vanish, and social evolution will retrograde. On the other hand, overly optimistic writers foresee no such stringencies within the next several centuries. In considerable part, such implications have come about by treating extreme situations as though they were average or usual, by projecting trends that are not wholly relevant, or by assuming that a given volume of water can be "used" only once (the pessimistic view) or can be reused an infinite number of times (the optimistic view).

With an appreciation that he may be oversimplifying, the writer ventures that the United States can be assured of sufficient water of acceptable quality for essential needs within the early foreseeable future, provided that it (1) informs itself, much more searchingly than it has thus far, in preparation for the decisions that can lead to prudent and rational management of all its natural water supplies; (2) is not deluded into expecting a simple panacea for watersupply stringencies that are emerging; (3) finds courage for compromise among potentially competitive uses for water; and (4) accepts and can absorb a considerable cost for new water-management works, of which a substantial part will need be bold in scale and novel in purpose.

Although this general appraisal is derived for the conterminous United States in particular, it is equally valid for Hawaii and Alaska. Components of this generalization now will be examined at some length. 


\section{ELEMENTS OF WATER SUPPLY}

Nearly all the fresh water naturally avalable to man is derived from precipitation. Over the United States, excluding Alaska and Hawan, this ultımate source averages about $1.4 \mathrm{mgd}$ per $\mathrm{ml}^{2}$ (million gallons per day per square mile), or 30 inches a year. Of this, about $10 \mathrm{mgd}$ per $\mathrm{ml}^{2}(211 / 2$ inches a year) returns to the atmosphere as water vapor-by evaporation from water surfaces and wetlands and by evapotranspiration of vegetation (native and cultivated). The remainder, about $0.4 \mathrm{mgd}$ per $\mathrm{ml}^{2}$ (81/2 inches a year), sustains the flow of streams and contributes to ground storage (Langbein, 1949). This remainder constitutes the water potentially avallable for withdrawal to serve man's uses; it is equivalent to constant flow of $1,200,000 \mathrm{mgd}$ (million gallons per day) or 1,900,000 cfs (cubic feet per second).

In this paper, quantities of water are stated usually in millions of gallons per day. Common equivalents of this units are shown in the following table.

\section{Hydrauluc equivalents}

[Equivalent values are on the same horizontal line]

\begin{tabular}{|c|c|c|c|c|c|c|}
\hline $\begin{array}{l}\text { Millon gallons } \\
\text { per day (mgd) }\end{array}$ & $\begin{array}{l}\text { Millon gallons } \\
\text { per year (mgy) }\end{array}$ & $\begin{array}{l}\text { Gallons per } \\
\text { minute } \\
\text { (gpm) }\end{array}$ & $\begin{array}{l}\text { Cubic feet } \\
\text { per second } \\
\text { (cfs) }\end{array}$ & $\begin{array}{l}\text { Acre-feet } \\
\text { per day } \\
\text { (afd) }\end{array}$ & $\begin{array}{l}\text { Acre-feet } \\
\text { per year } \\
\text { (afy) }\end{array}$ & $\begin{array}{l}\text { Inches on } 1 \\
\text { square mile } \\
\text { per year } \\
\text { (In per mi }{ }^{2} \text { ) }\end{array}$ \\
\hline $\begin{array}{ll}1 & 0 \\
& 0027397 \\
& 0014400 \\
& 64632 \\
& 32585 \\
& 00089274 \\
& 047607\end{array}$ & $\begin{array}{rl}365 & 0 \\
1 & 0 \\
& 52560 \\
235 & 91 \\
118 & 96 \\
& 32585 \\
17 & 377\end{array}$ & $\begin{array}{rl}694 & 44 \\
1 & 9026 \\
1 & 0 \\
448 & 83 \\
226 & 29 \\
& 61996 \\
33 & 065\end{array}$ & $\begin{array}{rl}1 & 5472 \\
& 0042390 \\
& 0022280 \\
1 & 0 \\
& 50417 \\
& 0013813 \\
& 073668\end{array}$ & $\begin{array}{rl}3 & 0689 \\
& 0084079 \\
& 0044192 \\
1 & 9835 \\
1 & 0 \\
r & 0027397 \\
& 14612\end{array}$ & $\begin{array}{rl}1,120 & 15 \\
3 & 0689 \\
1 & 6129 \\
723 & 97 \\
365 & 00 \\
1 & 0 \\
53 & 333\end{array}$ & $\begin{array}{rl}21 & 002 \\
& 057541 \\
& 030244 \\
13 & 574 \\
6 & 8433 \\
& 018750 \\
1 & 0\end{array}$ \\
\hline
\end{tabular}

\section{PRECIPITATION}

Even in the "normal" year, precipitation on the conterminous United States ranges from more than $4 \mathrm{mgd} \mathrm{per} \mathrm{ml}^{2}$ ( 85 in. per year) locally in the Pacific Northwest to less than $0.2 \mathrm{mgd}$ per $\mathrm{ml}^{2}$ (4 in. per year) locally in the Pacific Southwest. (See pl. 1.) Between wet and dry years the range is even greater.

Precipitation is used immediately and directly by man to the extent that it sustains the soll water on which nonirrigated crop plants and native vegetation depend. On the basis of this relation to "use," three precipitation provinces can be discriminated:

1. Over about the eastern half of the United States-that 1s, over the Atlantic and Gulf Coastal Plains, Appalachian Highlands, Interior Low Plateaus, Interior Highlands, and most of the Central Lowland-average precipitation ranges about from 1 to $3 \mathrm{mgd}$ per $\mathrm{mi}^{2}$ (20-60 in. per year), changes only gradually from 
one place to another, and commonly reaches a seasonal maximum at or near the height of the growing season. Ordinarly it is ample for crop plants and for marketable native vegetation. In this province especially, to a certain extent man can manipulate soll-water storage to his advantage by land treatments and by water-retarding structures.

2. Over the western fringe of the Central Lowland and westward across the Great Plains, average precipitation diminishes from about 1 to about $0.5 \mathrm{mgd}$ per $\mathrm{ml}^{2}$ (20-10 $\mathrm{m}$. per year). The seasonal peak commonly occurs early in the growing season. In most of the province, only water-thrifty crops such as wheat can be grown without irrigation, even in the wetter years.

3. Over the Rocky Mountains, Columbia and Colorado Plateaus, Basin and Range province, Sierra-Cascade Mountains, and most of the Pacific Border, average precipitation ranges widely, from about 0.2 to about $4 \mathrm{mgd}$ per $\mathrm{ml}^{2}$ (4-85 or more $\mathrm{m}$. per year), and the greater amounts fall on the higher parts of the rugged terrain. Seasonal maximum comes in midwinter; summer preclpitation is nominal. Variation from month to month and from year to year is extreme. Here, softwood timber thrives on the better watered uplands and affords a profitable crop from lands not suited to most agricultural pursuits. On the lowlands, only the hardiest of forage and grain crops can be grown widely without irrıgation. Here the geographic distribution of precipitation and that of arable land are mismatched. In this province, therefore, except in a very local sense, the overriding purpose of management must be so to conserve water that it can be used at a remote place and a later time, in relation to place and time of precipitation.

It is owing to these and other disparities in precipitation, and in the water supplies which precipitation generates, that the necessities of water-supply management differ so greatly from one region to another.

\section{EVAPORATION AND TRANSPIRATION}

In the sense that precipitation constitutes gross water supply, evaporation from open-water surfaces-from lakes, reservoirs, streams, ponds, and bogs - and transpiration through vegetation constitute a preemptive, and heavy, tax by Nature. Man can do relatively little to diminsh the tax; he gains some advantage from it by substituting marketable vegetation for native species that are not marketable. Man increases the tax whenever he enlarges natural open-water areas or creates such areas artificially and whenever he irrigates land that naturally is "dry." Evapotranspiration-that is, the sum of evaporation from wetted surfaces and of transpiration by vegetation-aver- 
ages about $1.1 \mathrm{mgd}$ per $\mathrm{mi}^{2}$ (22 in. per year), nearly 75 percent of the precipitation; however, it varies greatly from one place to another.

Potential evaporation from open-water surface ranges about from 1 to nearly $5 \mathrm{mgd} \mathrm{per} \mathrm{mi}^{2}$ (20-90 in. per year). On the Atlantic Slope and Atlantic Coastal Plain, it ranges from 20 inches per year in northern Maine to 54 unches in southern Florida; over the Central Lowland and Great Plans, from 24 to nearly 40 inches per year on the north and 50 to 80 inches across Texas; over the Rocky Mountains, Intermountain Plateaus, and the Paclfic Mountains, from 20 inches in northwestern Washington to a maximum of about 90 inches in Death Valley and the lower basin of the Colorado River. Details have been published by the U.S. Weather Bureau (1959).

At such rates, the aggregate loss from open-water surfaces is substantial. Meyers (1962) estimates that it averages $21,100 \mathrm{mgd}$ $(23,641,000$ acre-feet per year) from the 17 Western States, distributed as follows: From 51 principal reservoirs and regulated lakes, 8,090 mgd or 38 percent of the aggregate; from 600 -odd other principal reservoirs and regulated lakes, $2,890 \mathrm{mgd}$; from other lakes exceeding 500 acres in area, $1,770 \mathrm{mgd}$; from principal streams and canals, $3,950 \mathrm{mgd}$; from small ponds and reservorrs, $3,010 \mathrm{mgd}$; and from small streams, $1,400 \mathrm{mgd}$. Per year, this loss from principal reservoirs, regulated lakes, small reservoirs, and ponds amounts to 8.1 percent of the total usable storage capacity.

Potential evapotranspiration-that which would occur under optimum soil-water conditions and optimum vegetal cover-generally is somewhat less than potential evaporation. As estımated by Thornthwaite (1952), potential evapotranspiration ranges about from 18 inches per year in the Rocky Mountain province to 60 inches per year in Death Valley and the lower basin of the Colorado River.

The crucial aspect of evapotranspiration is that it may, and over extensive areas commonly does, exceed precipitation. In oversimplified principle, if potential evapotranspiration exceed precipitation, the potential moisture requirement of vegetation is not satisfied in full, and water is not available for overland flow to streams. In other words, the climate is arid. Conversely, if evapotranspiration is less than precipitation, runoff is generated perennially. These generalizations are acceptable only as first approximations. Actually, some runoff may occur even though concurrent potential evapotranspiration is not satisfied-perennially or intermittently in the arid regions and intermittently in the humid regions. This situation can occur if: (1) Some runoff is generated by effluent ground-water seepage and (2) if the rate of precipitation exceeds infiltration capacity of the soil so that, however great evapotranspiration may be, part of tho precipi- 
tation is rejected at the land surface and becomes immediate overland flow.

Plate 2 shows mean potential for perennial yield of withdrawable water-that is, average precipitation minus average potential evapotranspiration. Notable is the relatively large area of water deficiency in the western regions-specifically, the area in which potential evaporation and potential transpiration exceed precipitation and which ordinarily does not contribute perennially to water yield. This area encompasses the westernmost part of the Central Lowland and virtually all the Great Plains; much of the Rocky Mountains, the Columbia and Colorado Plateaus, and the Basin and Range province; and a considerable part of the Pacific Border province in California. Conversely, essentially all the eastern half of the 48 States is an area of potential water surplus which contributes to perennial water yield; there, evaporation and transpiration are exceeded by precipitation.

In the western region of general water deficiency, areas of potential water surplus exist only over the higher and mountainous uplands and over intermountain lowlands northward from San Francisco Bay. These discontinuous and relatively inextensive areas generate nearly all the perennial streamflow in the West.

Being based on average yearly precipitation and evapotranspiration, the areal pattern of plate 2 is itself an average. The areas of surplus or deficiency enlarge and diminish reciprocally from one season to another and from a wet year to a dry year. However, the major feature of the pattern persists-a water-plentiful or humid East and a water-deficient or arid West.

\section{STREAMFLOW}

The preemptive tax of evaporation and transpiration having been satisfied, the remainder of the gross water supply (precipitation) sustains the sources from which man can withdraw fresh water for his uses. These sources are the streams, natural lakes, manmade reservoirs, and bodies of ground water. Over any long term of years, neither lakes, reservoirs, nor ground-water bodies increase the freshwater supply potentially available in the streams, except to the extent that they may be unwatered permanently (a ground-water body thus unwatered is said to be "mined"). Thus, for the purposes of this report, it suffices to measure use and prospective demand of water against streamflow alone.

On the average, aggregate flow of the streams is about $81 / 2$ inches a year or $0.4 \mathrm{mgd}$ per $\mathrm{mi}^{2}$. This flow is fivefold greater than present withdrawals of water for use and twentyfold greater than consump- 
tion in use. However, the comparison is meaningless because both use and supply of water (in this instance, streamflow) are neither uniform from place to place nor constant in time. Indeed, the variability of streamflow is a basic obstacle to full use of all streams; some principal facets of this obstacle are summarized below and are shown by plate 3 .

Different regions yreld greatly different quantities of streamflow : A minimum from the arid Southwest and a maximum from the Pacific Northwest. Among individual stream basins, maximum yield (per unit of area) is roughly 200 -fold greater than the minimum. In contrast, in the humid East, maxımum yield is less than tenfold greater than the minimum. There are other contrasts of interest: 66 percent of the streamflow occurs east of the Mississippi River (tributaries of the Mississippi from the west excluded); the relatively small Pacific Northwest, which includes the Columbia River and other Pacific slope streams in Washington and Oregon, yields 13 percent of the streamflow from all the 48 conterminous States, and 72 percent of that from all the Pacific slope; this yield of Pacific Northwest streams is 1.1-fold greater than that of all tributaries to the Mississippi from the west and 3.1-fold greater than that of western Gulf streams. These geographic variations in stream yield match neither present nor prospective patterns of water use.

As has been implied, most streamflow in the West is generated on uplands and but little is generated on lowlands. Yet man's occupancy is almost exclusively in the lowlands. Here, then, the water supply must be managed at places remote from points of use.

In virtually all streams, flow varies from one year to another, from one season to another, and even from one hour to another. This variablity is of paramount consequence to use of the stream by man because, unless flows are regulated artificially, assured withdrawal can be no more than natural minimum flow and, if the variability is large, a major part of the total flow may pass unused. An example of a river having minimum variability is the St. Lawrence River, whose flow is regulated naturally by the very large storage capacity of the Great Lakes. On this stream, maximum yearly flow is only 1.5-fold greater than the minimum; maximum monthly flow, 20 -fold greater. (See pl. 3.) In contrast, in numerous principal streams, maximum yearly flow is fivefold or more greater than the minımum, and maximum monthly flow is tenfold or more greater. Flows so variable occur in streams both large and small They are notably common in streams of the Great Plains province, the western part of the Gulf Coastal Plain, and the southern part of the Basin and Range and Pacific Border provinces. 
Variation of flow with the seasons may or may not be a disadvantage-a disadvantage when greatest flow and greatest use occur in different seasons but an advantage when they fall in the same season.

The extreme events of fluctuating streamflow are floods and droughts. Both recur at irregular intervals of time. Floods are of short duration, but commonly their volume is much greater than can be contained practically by reservoirs. In this situation, flood management aims at passing the excess volume downstream with a minimum of damage but, also, with little or no use. The water so passed and unavailable for use may be a considerable part of total streamflow. Floods are especially troublesome in Atlantic slope basins northward from the Chesapeake Bay; in the Ohio River, Missouri River, and lower main-stem segments of the Mississippi River basin; and also in the Columbia River basin and other parts of the Pacific slope.

By definition, drought is an event more prolonged or notably more severe than the ordinary dry season. Thus, even though it may occur infrequently, commonly it induces the greatest withdrawals of water and so limits the assured capability of water-supply systems. Drought has been most notable over parts of the Great Plains, Basin and Range, and southernmost Pacific Border provinces.

To the extent that his requirements exceed natural minimum streamflow, man must suppress these geographic and temporal variations of water yield. The principal and all but exclusive means to this end is detaining streamflow in reservoirs during intervals of surplus flow and releasing the stored water during intervals of deficient natural flow. (See fig. 1.) Even so, however, all the natural streamflow never can be captured and withdrawn, because reservoirs inevitably increase the open-water area from which evaporation preempts its toll. In other words, the ultımate water-supply capability of a stream basin is something less than its average natural yield. (See also Langbein, 1959.) The difference between supply capability and average natural yield increases as the natural variability in streamflow increases, especially as the range widens between maxımum and minimum yearly flows. (Present investigations indicate that, if a fatty-alcohol film can be maintained on the surface of a reservoir, evaporation will diminish moderately but will not be eliminated.)

Reservoirs cost money, and ordinarily the cost per unit volume of water they control increases as successive reservoirs are constructed in a given stream basin. Thus, limits of acceptable cost may also determine the extent to which man will suppress the natural variations of streamflow-that is, will "regulate" the flow-to increase 
usable water supply. At this economic limit, an appreciable fraction of streamflow ordinarily will remain unused in the wetter years or seasons.

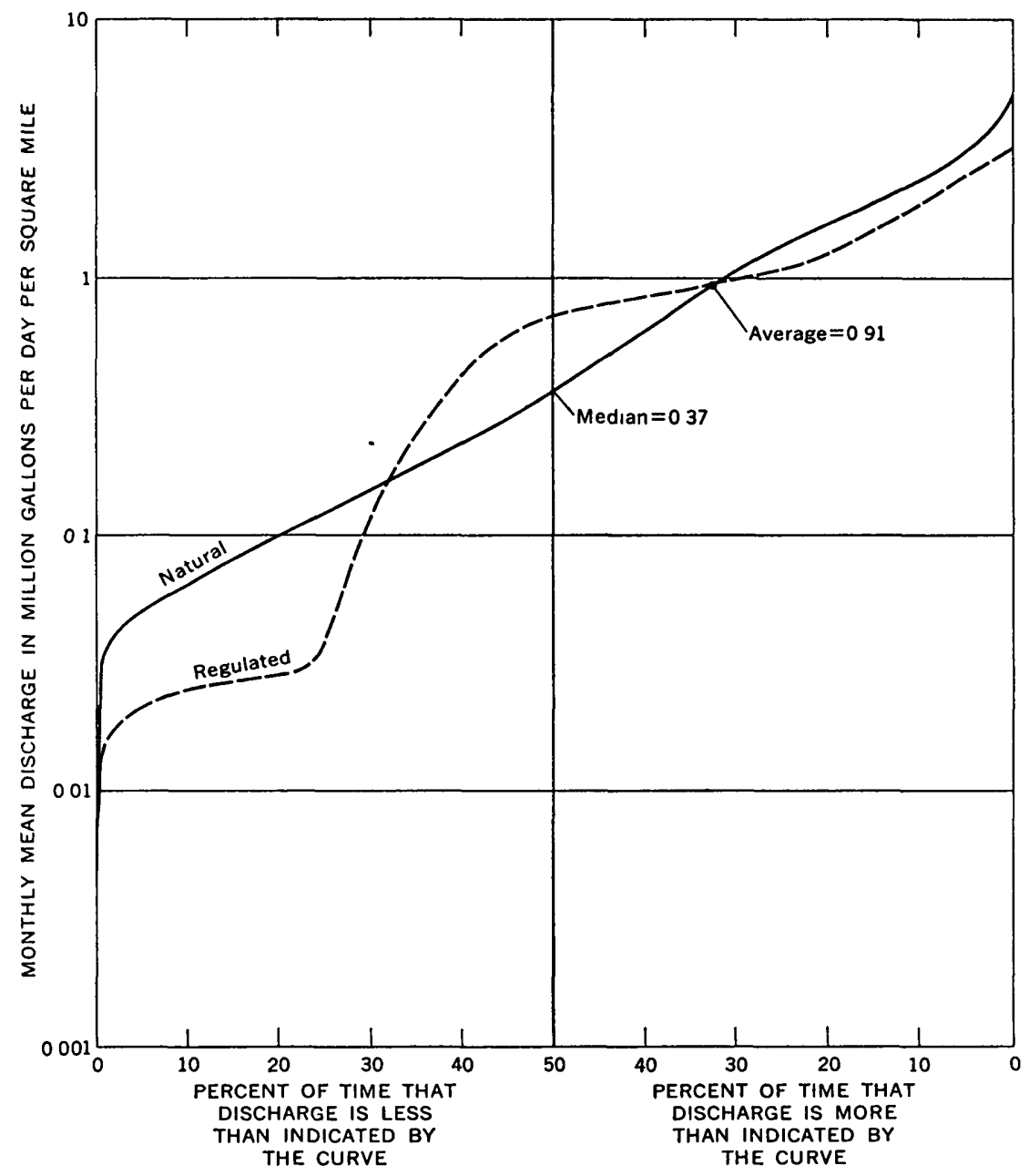

Figure 1-Natural and regulated streamflow, Merced River at Exchequer, Callf Jsable capacity of the reservior here is about 29 percent of the average yearly runoff The streamflow is regulated for generating hydroelectric power in one plant of a wide-fiung system, the particular plant operates intermittently to provide "peaking capacity"

Under regulation, both low flows and high flows of the natural regimen are diminished (60 percent of the time), but medium-range flows are increased (40 percent of the time) The regulated flow has been near the natural average 20 percent of the time and greater than the natural median about 60 percent of the time

If this reservolr were operated to meet a conHuuous, steady demand (rather than an intermittent, fluctuating demand), the controlled flows would have been substantlally less 
The limit of practicable streamflow regulation to increase dependable yield of water depends upon a complex of conditions unique to each stream basin. For the purposes of this report, it will be assumed that the greatest regulated yield that can be sustained continuously would, under conditions of natural flow, have been exceeded 50 percent of the time-in other words, that the limit of continuous regulated yield is about equal to median natural flow, regionwide. For no major stream of the United States has the water yield yet been so fully regulated; in one basin, that of the Colorado River, works now authorized or under construction will increase aggregate regulating capability almost to the assumed limit.

With water yleld at the assumed perennial limit, from one-fourth to three-fourths of natural streamflow may be considered perennially usable; nationwide, somewhat more than half. This degree of perennial yield probably will not be reached on all major streams, but on some it probably can be exceeded feasibly. For clarity, it is emphasized that the preceding discussion of streamflow regulation is wholly about achieving maximum perennial water yield. It should not be overlooked that regulation may be desirable for a purpose other than increased yield or may be justifiable for a purpose that sacrifices potential yield in some measure.

On most major streams, the assumed limit of continuous regulated yreld cannot be achieved at a cost that currently is acceptable. However, acceptable cost of managing and regulating water sources will increase, inevitably and substantially. The writer believes that eventually construction of additional storage for greater regulated yield will be limited principally by major engineering complexities, competition with other potential uses for the land of reservoir sites, or competition with other objectives of stream management.

\section{WATER-SUPPLY ELEMENTS BY REGIONS}

The preceding discussion emphasizes the considerable variation of each water-supply element from one region to another. More meaningful values for the several elements can be derived according to water-resource regions of which each is relatively homogeneous in respect to water yield. Figure 2 shows the water-resource regions that have been adopted for this report; in the main they are coextensive with the regions adopted by the Select Committee on National Water Resources. Tables 1, 2, and 3 summarize water-supply components by these regions. 


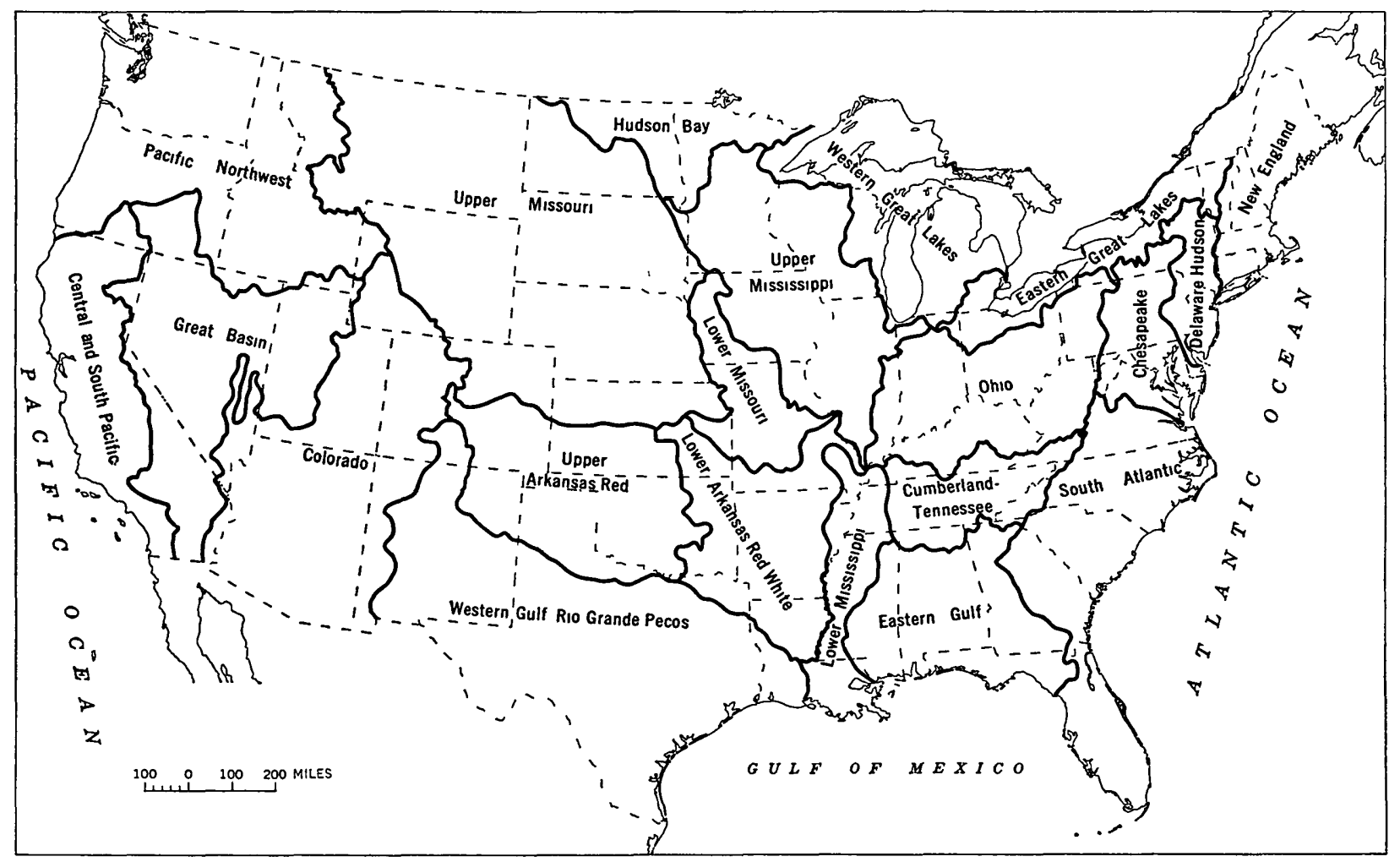

FIGURE 2-Water-supply and water-use regions of the conterminous United States Each of the regions outluned either is dominated by a single major source of water or encompasses several sources that are similar in magnitude and variability 
TABLE 1.-Approximate mean water-supply elements, by regions

\begin{tabular}{|c|c|c|c|c|c|c|c|c|c|}
\hline \multirow{3}{*}{ Region } & \multirow{3}{*}{$\begin{array}{c}\text { Area } \\
\left(\mathrm{mi}^{2}\right) \\
\\
(1) \\
\end{array}$} & \multirow{3}{*}{$\left|\begin{array}{c}\text { Precipitation } \\
\text { (mgd per mi2) } \\
(2)\end{array}\right|$} & \multirow{3}{*}{$\begin{array}{c}\begin{array}{c}\text { Potential } \\
\text { eveporation } \\
\text { (mgd per mí) }\end{array} \\
\text { (3) }\end{array}$} & \multirow{3}{*}{ 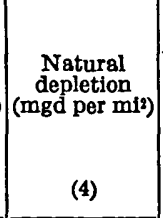 } & \multicolumn{2}{|c|}{ Natural runoff } & \multicolumn{3}{|c|}{ Depleted runoff, as of 1960} \\
\hline & & & & & \multirow{2}{*}{$\begin{array}{c}\mathrm{mgd} \text { per } \mathrm{mi}^{2} \\
(5)\end{array}$} & \multirow{2}{*}{$\begin{array}{l}\text { mgd } \\
(6)\end{array}$} & \multirow{2}{*}{$\begin{array}{c}\text { A verage } \\
\text { (mgd) } \\
\vdots \\
(7)\end{array}$} & \multicolumn{2}{|c|}{ Median } \\
\hline & & & & & & & & $\begin{array}{c}\mathrm{mgd} \\
(8)\end{array}$ & $\begin{array}{l}\text { Percent } \\
\text { (9) }\end{array}$ \\
\hline 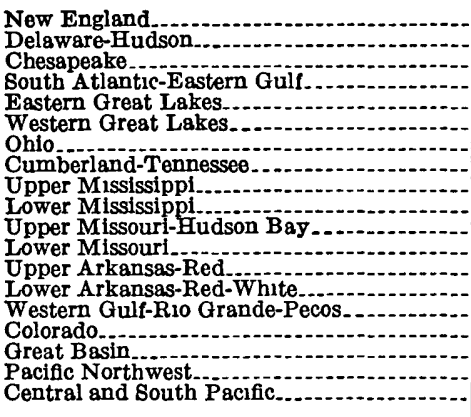 & $\begin{array}{r}62,500 \\
36,500 \\
67,600 \\
274,300 \\
48,300 \\
89,500 \\
143,400 \\
60,300 \\
184,800 \\
61,900 \\
509,100 \\
54,100 \\
171,500 \\
112,600 \\
331,100 \\
255,300 \\
191,800 \\
250,100 \\
122,000 \\
\end{array}$ & $\begin{array}{ll}1 & 93 \\
1 & 97 \\
1 & 97 \\
2 & 55 \\
1 & 71 \\
1 & 37 \\
2 & 02 \\
2 & 42 \\
1 & 45 \\
2 & 48 \\
81 \\
1 & 67 \\
1 & 07 \\
2 & 12 \\
1 & 15 \\
52 \\
1 & 48 \\
1 & 15 \\
1 & 11 \\
\end{array}$ & $\begin{array}{ll}1 & 16 \\
1 & 58 \\
1 & 56 \\
2 & 57 \\
1 & 26 \\
1 & 33 \\
1 & 52 \\
1 & 66 \\
1 & 58 \\
2 & 12 \\
1 & 86 \\
1 & 88 \\
2 & 84 \\
2 & 219 \\
2 & 93 \\
2 & 67 \\
2 & 20 \\
1 & 39 \\
2 & 24 \\
\end{array}$ & $\begin{array}{rl}0 & 84 \\
1 & 06 \\
1 & 20 \\
1 & 77 \\
86 \\
89 \\
1 & 24 \\
1 & 42 \\
1 & 11 \\
1 & 67 \\
1 & 75 \\
1 & 24 \\
1 & 98 \\
1 & 42 \\
98 \\
48 \\
44 \\
54 \\
60 \\
\end{array}$ & $\begin{array}{r}109 \\
.91 \\
77 \\
78 \\
85 \\
48 \\
78 \\
100 \\
34 \\
81 \\
058 \\
43 \\
088 \\
70 \\
17 \\
.044 \\
.042 \\
.61 \\
51 \\
\end{array}$ & $\begin{array}{r}67,900 \\
33,300 \\
52,000 \\
214,700 \\
40,900 \\
43,200 \\
111,400 \\
60,500 \\
63,600 \\
50,200 \\
29,700 \\
23,400 \\
15,100 \\
78,600 \\
56,800 \\
11,300 \\
8,100 \\
152,600 \\
62,300 \\
\end{array}$ & $\begin{array}{r}67,200 \\
31,700 \\
51,600 \\
212,000 \\
40,300 \\
42,500 \\
110,500 \\
59,800 \\
62,400 \\
48,800 \\
18,500 \\
23,100 \\
11,000 \\
76,900 \\
46,100 \\
3,170 \\
3,750 \\
143,000 \\
48,200 \\
\end{array}$ & $\begin{array}{r}39,400 \\
18,700 \\
31,700 \\
126,000 \\
19,400 \\
31,700 \\
45,900 \\
36,200 \\
40,700 \\
21,300 \\
9,050 \\
5,820 \\
4,520 \\
20,000 \\
14,200 \\
1,680 \\
2,130 \\
75,600 \\
15,700 \\
\end{array}$ & $\begin{array}{l}59 \\
59 \\
61 \\
59 \\
48 \\
75 \\
41 \\
60 \\
65 \\
44 \\
49 \\
25 \\
41 \\
26 \\
31 \\
54 \\
57 \\
53 \\
33 \\
\end{array}$ \\
\hline Total or mean & $3,026,700$ & 133 & 205 & 94 & 39 & $1,175,600$ & $1,100,500$ & 559,700 & 51 \\
\hline
\end{tabular}

Column:

1960, however, this consumption is very largely from naturally wet areas and is therefore more a component of Nature's preemptive "take" of water than an effect of activities by man In other words, current "on-site" use is not chargeable as a
depletion or current runoff
Here and elsewhere in this report, runoff and water yield credited to each of the Here and elsewhere in this report, runoff and water yield credited to each of the are parts of two major river basins, those of the St Lawrence River and the Mississippi River Thus, runoff credited to the western Great Lakes and eastern Great Lakes cannot be accumulated to show main-stem fow, because yield from the part of the basin in Canada is excluded Main-stem flow of the Mississippi River may be sequence

7 and $8-$ After Oltman and others (1960)

9 -Percent of average

Douglas (1932, $p$ 248) for aggregate area of land and water except "that part of Water area the Creat Lakes, the Atlantic Ocean, the Gull of Mexico, the Pact

2 and 3 -After US Weather Bureau $(1050,1060)$, odjusted to destnoute appar discrepancies among columns 2 to

5 and 6 -Depleted runoff as of 1960 (after Oltman and others, 1960) plus water consumed in use as of 1960 (after MacKuchan and Kammerer, 1961) plus depletion by reservolrs (from table 2) "On-site" consumption of water here is excluded Such wetlands, and by fish hatcheries-has been estimated by Eliasberg (1960) As of 
TABLE 2.-Reservours and regulated lake8, existing and under construction as of 1954

\begin{tabular}{|c|c|c|c|c|c|c|c|}
\hline \multirow{2}{*}{ Region } & \multicolumn{2}{|c|}{ Usable capacity } & \multirow{2}{*}{$\begin{array}{c}\text { Surface } \\
\text { ares } \\
\text { (acres) } \\
\text { (3) }\end{array}$} & \multirow{2}{*}{$\begin{array}{c}\begin{array}{c}\text { Effectlve } \\
\text { depth } \\
\text { (feet) }\end{array} \\
\text { (4) }\end{array}$} & \multicolumn{3}{|c|}{ Yearly net depletion } \\
\hline & $\begin{array}{l}\mathrm{mg} \\
(1)\end{array}$ & $\begin{array}{c}\text { Days } \\
\text { (2) }\end{array}$ & & & $\begin{array}{c}\text { Feet } \\
(5)\end{array}$ & $\begin{array}{l}\mathrm{mg} \\
(6)\end{array}$ & $\begin{array}{c}\text { Percent } \\
\text { (7) }\end{array}$ \\
\hline 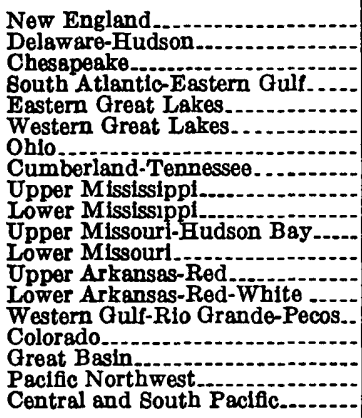 & $\begin{array}{r}2,898,000 \\
992,400 \\
309,100 \\
5,334,000 \\
543,300 \\
419,600 \\
1,875,000 \\
6,957,000 \\
1,138,000 \\
1,465,000 \\
24,720,000 \\
406,000 \\
2,472,000 \\
7,275,000 \\
4,667,000 \\
11,326,000 \\
1,659,000 \\
9,082,000 \\
5,612,000\end{array}$ & $\begin{array}{r}43 \\
30 \\
6 \\
25 \\
13 \\
10 \\
17 \\
115 \\
18 \\
29 \\
832 \\
17 \\
164 \\
93 \\
82 \\
1,002 \\
205 \\
60 \\
88\end{array}$ & $\begin{array}{r}840,000 \\
903,000 \\
50,500 \\
1,500,000 \\
261,000 \\
305,000 \\
226,000 \\
895,000 \\
808,000 \\
208,000 \\
2,140,000 \\
59,700 \\
317,000 \\
699,000 \\
483,000 \\
306,000 \\
398,000 \\
982,000 \\
436,000\end{array}$ & $\begin{array}{rr}10 & 6 \\
3 & 4 \\
18.8 \\
10 & 9 \\
6 & 4 \\
4.2 \\
25 & 5 \\
23 & 9 \\
4.3 \\
21 & 4 \\
35 & 4 \\
20 & 9 \\
23 & 9 \\
31 & 9 \\
29 & 7 \\
113 & 6 \\
12 & 8 \\
28 & 4 \\
38.8 & \end{array}$ & $\begin{array}{rr}0 & 65 \\
92 \\
64 \\
\\
\\
54 \\
71 \\
78 \\
.47 \\
.42 \\
.42 \\
82 \\
1 \\
1 & 94 \\
1 & 13 \\
3 & 24 \\
1 & 34 \\
3 & 42 \\
3 & 84 \\
3 & 08 \\
1 & 50 \\
2 & 87 \\
\end{array}$ & $\begin{array}{r}149,000 \\
270000 \\
10,600 \\
262,000 \\
60,000 \\
77,400 \\
34,000 \\
122,000 \\
216,000 \\
53,800 \\
1,353,000 \\
21,900 \\
335,000 \\
304,000 \\
538,000 \\
383,000 \\
400,000 \\
480,000 \\
408,000\end{array}$ & $\begin{array}{r}5 \\
27 \\
3 \\
5 \\
11 \\
18 \\
18 \\
2 \\
2 \\
19 \\
4 \\
5 \\
5 \\
5 \\
14 \\
4 \\
12 \\
3 \\
24 \\
5 \\
5 \\
7\end{array}$ \\
\hline Total or mean..... & $89,040,000$ & 76 & $11,820,000$ & 231 & 142 & $5,479,000$ & 6 \\
\hline
\end{tabular}

\section{Column}

1 -Summarized from Thomas and Harbeck (1956), Includes those reservolrs and regulated lakes whose capacity is 5,000 acre-feet or more, generally without flashboards

2-Column 1 divided by column $B$ of table 1 For any single reservoir, this capacity ratio indicates the time required to impound or release a volume of water equal to the usable capacity, it assumes a rate equal to that of mean runof Among the 19 reglons, only in the upper Missouri-Hudson Bay and Colorado does usable capacity exceed average yearly runoff In $\theta$ of the 19 reglons, usable capacity is less than 10 percent of average yearly runofi-that is only a minor part of the water supply is provided by reservoirs These nine regions span 32 percent of the Nation's area-all the Atlantic slope and eastern Gulf areas, excopt Now England, and also the Ohio, Upper Mississippi, Lower Mississippi, and Lower Missouri regions 3.- Summarized from Thomas and Harbeck (1956)

4 -Column 1 divided by column 3 , each converted to appropriate units Other factors being the same, the greater the effective depth, the smaller the proportion of stored water that evaporates

5- Potential evaporation minus the depletion that would have occurred naturally had the reservoir not existed. This column is derived from table 1 - specifically, column 3 munus column 4 of that table, or column 8 minus column 2 plus column 5 , converted to yearly depth in feet.

6 -Column 3 multiplied by column 5 , and the product converted to million gallons a day.

7-Percent of usable capacity - that is, column 6 divided by column 1 As has been stated, the greater the effective depth, the less the percentage depletion, other factors being the same Note in particular that percentage depletion is greatest in the Delaware-Hudson reglon even though potential evaporation is comparatively small, presumably because effective depth is least In contrast, percentage depletion is small in the Colorado reglon even though potentlal evaporation is large, in this region, effective depth is severalfold greater than in any other of the regions 
TABLE 3.-Reservours required to assure flow equal to present median flow

\begin{tabular}{|c|c|c|c|c|c|c|}
\hline \multirow{2}{*}{ Region } & \multirow{2}{*}{$\begin{array}{c}\text { Additional } \\
\text { capacity } \\
\text { (mg) } \\
\text { (1) }\end{array}$} & \multicolumn{2}{|c|}{ Total capacity } & \multirow{2}{*}{$\begin{array}{c}\text { Surface } \\
\text { area (acres) }\end{array}$} & \multicolumn{2}{|c|}{$\begin{array}{l}\text { Total yearly } \\
\text { net depletion }\end{array}$} \\
\hline & & $\begin{array}{l}\mathrm{mg} \\
(2)\end{array}$ & $\begin{array}{c}\text { Days } \\
\text { (3) }\end{array}$ & & $\begin{array}{r}\mathrm{mg} \\
(5)\end{array}$ & $\begin{array}{c}\text { Percent } \\
(6)\end{array}$ \\
\hline 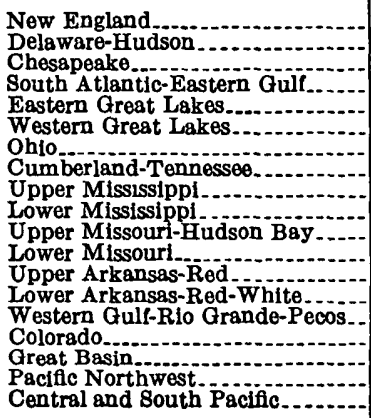 & $\begin{array}{r}8,500,000 \\
3,600,000 \\
6,500,000 \\
25,400,000 \\
3,600,000 \\
6,500,000 \\
9,400,000 \\
4,100,000 \\
8,500,000 \\
4,600,000 \\
1,900,000 \\
1,700,000 \\
1,100,000 \\
7,200,000 \\
3,900,000 \\
390,000 \\
320,000 \\
15,300,000 \\
3,600,000\end{array}$ & $\begin{array}{r}11,400,000 \\
4,600,000 \\
6,800,000 \\
30,700,000 \\
4,100,000 \\
6,900,000 \\
11,300,000 \\
11,000,000 \\
9,600,000 \\
6,100,000 \\
26,600,000 \\
2,100,000 \\
3,600,000 \\
14,500,000 \\
8,600,000 \\
11,700,000 \\
2,000,000 \\
24,400,000 \\
9,100,000\end{array}$ & $\begin{array}{r}170 \\
140 \\
130 \\
140 \\
100 \\
160 \\
100 \\
180 \\
150 \\
120 \\
900 \\
90 \\
240 \\
180 \\
150 \\
1,040 \\
250 \\
160 \\
150\end{array}$ & $\begin{array}{r}1,700,000 \\
950,000 \\
1,400,000 \\
3,800,000 \\
840,000 \\
1,400,000 \\
1,400,000 \\
1,400,000 \\
2,000,000 \\
750,000 \\
2,300,000 \\
320,000 \\
440,000 \\
1,500,000 \\
880,000 \\
360,000 \\
410,000 \\
2,100,000 \\
700,000\end{array}$ & $\begin{array}{r}305,000 \\
285,000 \\
292,000 \\
669,000 \\
194,000 \\
356,000 \\
214,000 \\
192,000 \\
534,000 \\
193,000 \\
1,450,000 \\
118,000 \\
465,000 \\
655,000 \\
981,000 \\
450,000 \\
411,000 \\
1,030,000 \\
655,000\end{array}$ & $\begin{array}{r}3 \\
6 \\
4 \\
2 \\
5 \\
5 \\
2 \\
2 \\
6 \\
3 \\
5 \\
6 \\
13 \\
5 \\
11 \\
4 \\
20 \\
4 \\
7\end{array}$ \\
\hline Total or mean. & $116,000,000$ & $205,000,000$ & 170 & $24,650,000$ & $9,449,000$ & 5 \\
\hline
\end{tabular}

Column

1 -After Oltman and others (1960)

2 -Column 1 plus column 1 of table 2

3 -To nearest multiple of 10 days See explanation of table 2, column 2 Note that, to assure flow equal to present median flow, usable storage capacity must exceed 25 percent of average natural yearly runoff in all regions, and exceed 50 percent in 6 of the 19 regions In two of the latter six - the Upper Missouri-Hudson Bay and Colorado regions-required usable capacity would be 25 -fold and 28-fold greater than average yearly runoff, respectively Thus, in dry years, most of the streams in most of the regions would need to be regulated continuously to assure flow not less than present median flow As has been stated elsewhere natural median flow approaches the maximum perennial water supply that can be developed practicably under ordinary environmental and economic circumstances

4-Order-of-magnitude estimate only The estimates take into account the expectation that future reservoirs will have greater effective depth and smaller percentage depletion

5 -Column 4 multiplied by column 5 of table 2 , and the product converted to million gallons a day 6-Column 8 divlded by column 2. 


\section{PRESENT AND PROSPECTIVE USE OF WATER}

\section{THE OVERALL SITUATION}

As of 1960 , the aggregate of all water withdrawals in the 48 conterminous States was about 270,000 $\mathrm{mgd}$, of which about $68,000 \mathrm{mgd}$ was consumed by evaporation in the course of use (MacKichan and Kammerer, 1961). By categories of use, these amounts were distrıbuted as shown in table 4 :

TABLE 4 - Water withdrawn and water consumed, 1960

[After MacKıchan and Kammerer (1961), modified]

\begin{tabular}{|c|c|c|c|c|}
\hline \multirow{2}{*}{ Use } & \multicolumn{2}{|c|}{ Withdrawn } & \multicolumn{2}{|c|}{ Consumed } \\
\hline & mgd & Percent & $\mathrm{mgd}$ & Percent \\
\hline $\begin{array}{l}\text { Rural } \\
\text { Public supplies } \\
\text { Self-supphied industry }\end{array}$ & $\begin{array}{r}3,600 \\
21,000 \\
140,000\end{array}$ & $\begin{array}{rl}1 & 3 \\
78 & 8 \\
52\end{array}$ & $\begin{array}{l}2,800 \\
3,500 \\
3,200\end{array}$ & $\begin{array}{l}4.1 \\
5.2 \\
4.7\end{array}$ \\
\hline $\begin{array}{l}\text { Conveyance losses........ } \\
\text { Delivered to farms }\end{array}$ & $\begin{array}{l}23,000 \\
83,000\end{array}$ & $31^{85}$ & $\begin{array}{r}17,500 \\
251,000\end{array}$ & $\frac{11}{75}$ \\
\hline Totals (rounded) & 8270,000 & 100 & 68,000 & 100 \\
\hline
\end{tabular}

1 Commonly it is assumed that all the water lost in convey ance by irrigation canals returns ultimately to the streams However, transpiration by canal-bank vegetation is appreciable in some areas The writer postulates that, from this cause and others, about one-third of the gross conveyance loss is removed permanently from the stream system

2 Water consumed by nonirrigated crops is even greater in amount but is taken from soll water which, in the context of this paper, is not withdrawable.

${ }^{3}$ Includes 32,000 mgd of saline water

Thus, as of 1960, total consumption of water in the course of use $(68,000 \mathrm{mgd})$ was about 25 percent of the aggregate withdrawn from all water sources $(270,000 \mathrm{mgd})$ but somewhat less than 6 percent of aggregate streamflow (1,200,000 mgd). Among the several categories of use, consumption was about 23 percent of the withdrawal for selfsupplied industry, 17 percent of that for public supplies, 55 percent of that for irrigation, and 78 percent of the small withdrawal for rural uses.

Like streamflow, these uses of water fluctuate. Use from public supplies may increase severalfold during summer, largely for watering grounds and for air conditioning; obviously this seasonal increase is greatest in the warmer and drier regions. As a whole, industrial use is relatively constant throughout the year, although locally and for certain industries - such as food processing - the water requirement is seasonal and fluctuates widely. Use for irrigation is almost wholly within the growing season and is virtually nll in 6 to 9 months of the year.

Seasonal fluctuation in water use is much greater in the West, where most of the irrigation use occurs, and is of small consequence in the industrial East. In both the West and the East, however, a large 
part of the aggregate water use is focused in relatively small but intensively developed areas-the metropolitan centers, major industrial complexes, and principal irrigated tracts.

Thus, water use varies both in time and in place, and commonly its variations do not match those of the water sources. Water demand commonly is large when yield of the water sources is small, and large demands commonly arise in areas remote from large water sources. This mismatch is an all-pervading problem of water-supply management.

Withdrawal use of water in the United States increases; at the current rate of mcrease, aggregate use would double in 25 to 30 years. Even greater rates of increase have been projected by Wollman (1960, p. 6, 79-121), who has estımated water withdrawn and water consumed as of 1980 and 2000 Table 5 summarizes his estimates.

TABLE 5.-Estimated water withdrawn and water consumed, 1980 and 2000

[After Wollman (1960), in millions of gallons per day]

\begin{tabular}{|c|c|c|c|c|}
\hline \multirow{2}{*}{ Use } & \multicolumn{2}{|c|}{ Withdrawn } & \multicolumn{2}{|c|}{ Consumed } \\
\hline & 1980 & 2000 & 1980 & 2000 \\
\hline $\begin{array}{l}\text { Municipal (public supphes) } \\
\text { Mining, manufacturing, and steam-electric (industry) } \\
\text { Agriculture (rural and irrigation) }\end{array}$ & $\begin{array}{r}29,000 \\
363,000 \\
167,000\end{array}$ & $\begin{array}{r}42,000 \\
662,000 \\
184,000 \\
\end{array}$ & $\begin{array}{r}3,500 \\
11,000 \\
104,000 \\
71,000\end{array}$ & $\begin{array}{r}5,500 \\
24,000 \\
126,000 \\
97,000\end{array}$ \\
\hline Totals...... & 559,000 & 888,000 & 190,000 & 253,000 \\
\hline
\end{tabular}

1 Water consumed by "on-site" uses comprises the effects of land treatment and structures, enlarged swamps and wetlands, and fish hatcheries In large part, water consumed by such uses is intercepted before it has entered a perennial stream, in other words, streamflow is depleted even though water may not be withdrawn in the usual sense

Owing to past and present depletion of this kind, accepted values of streamflow as measured and published by the U S Geological Survey presumably are smaller than natural flows Thus, present on-site consumption is not charged as an encumbrance against measured water supply However, the estimates of on-site consumption as of 1980 and 2000 are for expected increases in such consumption, these must be charged against avalable supply as now measured

The estimates of water withdrawn and water consumed as of 1980 and 2000 are based on medium-level projections of population, economic activity, and water use (Wollman, 1960, p. 5-6). They are accepted by the writer as credible first approximations for comparison with estimates of assured supply. From 1960 to 2000, they embody increases per decade of about 17 percent in population; 19 percent in water withdrawn for public supplies, but 12 percent in water consumed by such use; 47 percent in water withdrawn but 66 percent in water consumed by industry; and 14 percent in water withdrawn but 20 percent in water consumed in irrigation and rural uses.

Certain trends implied by these projections are noteworthy. Percapita withdrawal for public supplies would increase slightly but per-capita consumption would diminish 15 percent over the four decades. Such improvement in efficiency of water use is possible and 
desirable, but it is neither assured nor, in the writer's judgment, easily realized. Per capita withdrawal by industry would increase 2.6fold, per capita consumption 7.5-fold. These per capita increases seem inordinately large, although industry likely will consume an increasing proportion of its water. Irrigation withdrawals would increase 1.7-fold, and irrigation consumption 2.1-fold. These projections imply that the efficiency of urrigation use will decrease, whereas it should increase under technologic improvements.

According to Wollman's projections, by the year 2000 aggregate withdrawal would be no more than 74 percent of present streamflow; consumption would be 29 percent of withdrawals and 21 percent of streamflow. Of course, these percentages do not indicate that all the projected demands for water can be satisfied without depletion of any stream. Any such inference would be false on several points, including: (1) It would presume that either water or persons and their uses of water can be transported freely and completely in order to balance total water supply against total demand. Transportation so free is not practical. (2) It would presume that all the water yield that is surplus during the wetter seasons and years could be impounded and held for use during the drier seasons and years. As has been shown, the perennially dependable supply is substantially less than the theoretical average supply in all stream basins. (3) It presumes that all water withdrawn but not consumed remains usable for any purpose. Actually, any use of water depreciates the quality of the fraction not consumed; with repeated reuse, progressive depreciation in quality eventually makes some fraction of the supply unusable for many purposes. (4) It does not take into account necessary on-site and in-channel uses-for hydroelectric power, diluting and transporting fluid wastes, navigation, depletion by reservoirs, habitat for fish and waterfowl, and recreation-which, in the aggregate, may be severalfold greater than withdrawal uses.

\section{DEMAND AND SUPPLY BY REGIONS}

Tables 6 and 7 present a reasonably realistic comparison of the projected demand and supply of water as of the year 2000 , by types of use and by water-resources regions. (See fig. 2.) Implicit in this comparison are certain generalizations and assumptions, as follows:

1. Assured water supply is equal to median natural streamflow; for all the 48 conterminous States this median would be about 54 percent of total streamflow. (See p. 9.)

Wollman (1960) and Eliasburg (1960) derive "maximum low flow(s) that can be sustained" which, for all the 48 con- 
terminous States, aggregate 92 percent of total natural runoff and for certain regions are as much as 98 percent. In the writer's judgment, sustained yields so great would be virtually impossible to achieve region wide.

2. The potential yield of ground-water bodies can be realized only at the expense of an equal diminution in streamflow, over the long haul. In other words, ground-water sources do not increase the aggregate potential supply of water. This fact would become literally true if total potential yield were being put to use.

3. As derived by Wollman (1960) and Eliasburg (1960) and accepted for this report, projected demands for water are not scaled to supplies. Rather, each potential use or commitment of water is projected independently, as though it is preemptive; it is also projected according to estimated nationwide or regionwide requirement for the products derivable from the use. This basis leads to certain incongruously large projections, to which further reference will be made.

4. Biological oxygen demand (BOD) of municipal sewage and of industria] waste will be largely removed by treatment, and effluents from treatment plants will be diluted sufficiently to maintain dissolved oxygen at regionwide averages of 4 milligrams per liter. (This amount of dissolved oxygen is about the minimum for a satisfactory fish and wildlife habitat.) In the projections by Wollman and Eliasburg, the degree of waste treatment is either that which involves the least cost for treatment plant plus water for dilution or, in certain water-deficient regions, that which requires the least dilution. By these criteria, percentage BOD removal from sewage would range between 80 and 97.5 percent among the several regions; that from industrial wastes, between 50 and 97.5 percent. This degree of BOD removal is far greater than is now achieved regionwide. The greater of these BOD removals may not be achievable at acceptable costs; if not, requirements of water for dilution would be increased commensurately.

5. (a) Water allocated for in-channel uses-for hydroelectric power, waste dilution, navigation, habitat for fish and wildlife, and recreation-also will satısfy all withdrawal uses. (b) The water allocated to the largest in-channel use will suffice for all such uses. (c) In consequence, maximum net commitment against potential supply is the sum of water consumed in off-channel and on-site uses plus that allocated to the largest, or dominant, inchannel use. Strictly, this latter generalization is not valid; as a first approximation, however, it is acceptable. 
TABLE 6.-Projected demand and supply of water as of the year 2000, by types of demand and by regions

[In millions of gallons per day. After Eliasberg (1960), except as indicated in notes]

\begin{tabular}{|c|c|c|c|c|c|c|c|c|c|c|c|c|c|}
\hline \multirow[b]{2}{*}{ Region } & \multicolumn{4}{|c|}{ Water consumed in off-channel use } & \multicolumn{4}{|c|}{ Water consumed on site } & \multicolumn{2}{|c|}{$\begin{array}{c}\text { Dominant } \\
\text { in-channel flow }\end{array}$} & \multirow{2}{*}{ 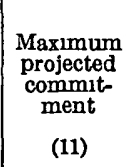 } & \multirow{2}{*}{$\begin{array}{c}\text { Potential } \\
\text { assured } \\
\text { supply } \\
\\
(12)\end{array}$} & \multirow{2}{*}{$\begin{array}{c}\text { Supply-to- } \\
\text { commit- } \\
\text { ment } \\
\text { ratio } \\
(13)\end{array}$} \\
\hline & $\begin{array}{c}\text { Munici- } \\
\text { palities } \\
\text { (1) }\end{array}$ & $\begin{array}{c}\text { Industry } \\
\text { (2) }\end{array}$ & $\begin{array}{c}\text { Agricul- } \\
\text { ture } \\
\text { (3) }\end{array}$ & $\begin{array}{c}\text { Subtotal } \\
\text { (4) }\end{array}$ & $\begin{array}{c}\underset{\text { Land }}{\text { treatment }} \\
(5)\end{array}$ & $\begin{array}{c}\text { Wetlands } \\
(6)\end{array}$ & $\begin{array}{c}\text { Reservour } \\
\text { depletion } \\
\text { (7) }\end{array}$ & $\begin{array}{c}\text { Subtotal } \\
(8)\end{array}$ & $\begin{array}{l}\text { Use } \\
(\theta)\end{array}$ & $\begin{array}{c}\text { Amount } \\
\text { (10) }\end{array}$ & & & \\
\hline 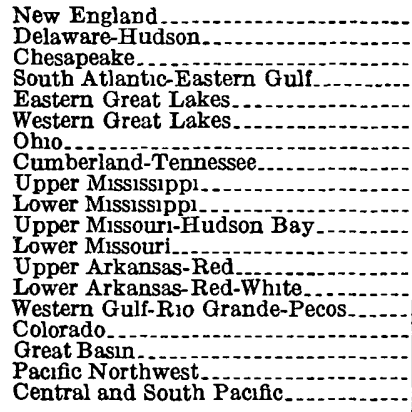 & $\begin{array}{r}200 \\
500 \\
200 \\
300 \\
400 \\
500 \\
300 \\
(1) \\
300 \\
100 \\
200 \\
(1) \quad 100 \\
{ }^{(1)} \\
500 \\
100 \\
100 \\
500 \\
1,200\end{array}$ & $\begin{array}{r}1,100 \\
1,000 \\
600 \\
3,400 \\
800 \\
2,500 \\
2,100 \\
500 \\
700 \\
500 \\
300 \\
100 \\
900 \\
700 \\
5,200 \\
1,100 \\
300 \\
900 \\
1,600\end{array}$ & $\begin{array}{r}300 \\
500 \\
1,200 \\
8,100 \\
600 \\
1,200 \\
1,800 \\
400 \\
4,600 \\
3,100 \\
20,500 \\
1,400 \\
4,600 \\
3,000 \\
14,800 \\
13,200 \\
6,100 \\
13,600 \\
27,500\end{array}$ & $\begin{array}{r}1,600 \\
2,000 \\
2,000 \\
11,800 \\
1,800 \\
4,200 \\
4,200 \\
900 \\
5,600 \\
3,700 \\
21,000 \\
1,500 \\
5,600 \\
3,700 \\
20,500 \\
14,400 \\
6,500 \\
15,000 \\
30,300\end{array}$ & $\begin{array}{r}500 \\
-200 \\
100 \\
900 \\
0 \\
100 \\
500 \\
400 \\
600 \\
300 \\
1,500 \\
200 \\
300 \\
700 \\
600 \\
100 \\
(1) \\
200 \\
100\end{array}$ & $\begin{array}{r}400 \\
1,300 \\
900 \\
19,900 \\
1,100 \\
3,600 \\
200 \\
100 \\
4,900 \\
9,500 \\
17,600 \\
100 \\
1,100 \\
2,000 \\
14,300 \\
2,600 \\
5,300 \\
1,200 \\
3,800\end{array}$ & $\begin{array}{r}840 \\
780 \\
800 \\
1,830 \\
530 \\
980 \\
590 \\
530 \\
1,460 \\
530 \\
3,970 \\
320 \\
1,270 \\
1,790 \\
2,690 \\
1,230 \\
1,130 \\
2,820 \\
1,790\end{array}$ & $\begin{array}{r}1,740 \\
1,880 \\
1,800 \\
22,630 \\
1,630 \\
4,680 \\
1,290 \\
1,030 \\
6,960 \\
10,330 \\
23,070 \\
620 \\
2,670 \\
4,490 \\
17,590 \\
3,930 \\
6,430 \\
4,220 \\
5,690\end{array}$ & 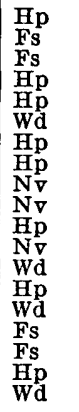 & $\begin{array}{r}26,800 \\
23,400 \\
33,000 \\
67,000 \\
101,800 \\
51,200 \\
35,700 \\
47,300 \\
48,500 \\
97,100 \\
25,000 \\
22,600 \\
4,600 \\
29,500 \\
18,400 \\
15,900 \\
4,000 \\
133,900 \\
36,000\end{array}$ & $\begin{array}{r}30,100 \\
27,300 \\
36,800 \\
101,400 \\
105,200 \\
60,100 \\
41,200 \\
49,200 \\
61,100 \\
111,100 \\
69,100 \\
24,700 \\
12,900 \\
37,700 \\
56,500 \\
34,200 \\
16,900 \\
153,100 \\
72,000\end{array}$ & $\begin{array}{r}40,000 \\
20,300 \\
32,000 \\
128,700 \\
20,000 \\
32,400 \\
46,800 \\
36,900 \\
41,900 \\
22,800 \\
20,300 \\
6,100 \\
8,600 \\
21,700 \\
24,900 \\
9,800 \\
6,500 \\
85,200 \\
29,800\end{array}$ & $\begin{array}{r}13 \\
74 \\
87 \\
13 \\
19 \\
194 \\
15 \\
1 \\
75 \\
69 \\
21 \\
29 \\
25 \\
67 \\
58 \\
44 \\
29 \\
38 \\
56 \\
41\end{array}$ \\
\hline Total_. & 5,500 & 24,300 & 126,500 & 156,300 & 6,900 & 89,900 & 25,880 & 122,680 & & 821,700 & $1,100,600$ & 634,700 & 58 \\
\hline
\end{tabular}

1 Less than $50 \mathrm{mgd}$

$2-$ Manufacturing, $20,900 \mathrm{mgd}$ over all the United States, steam-electric power, 2,800 mgd, muning, 600 mgd

3 - Chiefly irrigation
5 - Water that naturally would reach a stream, but that $1 \mathrm{~s}$ dissipated by landtreatment practices or structures Quantities represent increases above those of 1954 and so are chargeable as depletions of runoff (see note to table 1, columns 5 and 6 ) The negative quantity for the Delaware-Hudson region implies an increase in water yield owing to land-treatment measures

retlands and by fish hatcheries, both conardingly, the quantities are chargeable as future depletions of

7-From table 3, column 5

9 -Only the largest of potential in-channel water requirements is listed on the assumption that in-channel flow will be sufficient for all if the largest is satisfied
This assumption may or may not be valid Types of in-channel requirements include Hp, hydroelectric power, Fs, sport fishing habitat, Wd, waste dilution v, navigation

作 columns 4 and 8 If the coluantity is severalfold greater than the sum of those in 11 summation may be smaller tban the flow required to satisfy both off-channel and

12-Potential assured supply is assumed equal to median natural flow As an approximation of this median, the column 12 quantity is equal to column 8 from table plus depletion by reservoirs as of 1954 (table 2 column 6) The note to table 1 columns 5 and 6 , also applies In the Mississipp River basin, assured main-stem supply can be approximated by accumulating supplies of the several regions involved less water consumed off-channel and on-site, in downstream sequence 
TABLE 7.-Summary of projected demand and supply of water as of the year 2000, by regions

[In millon gallons a day per square mule]

\begin{tabular}{|c|c|c|c|c|c|c|c|c|}
\hline \multirow[b]{2}{*}{ Region } & \multicolumn{6}{|c|}{ Demand } & \multicolumn{2}{|c|}{ Supply } \\
\hline & $\begin{array}{c}\text { Consumed } \\
\text { in use } \\
\text { (1) }\end{array}$ & $\begin{array}{c}\text { Consumed } \\
\text { on site } 1 \\
\text { (2) }\end{array}$ & $\begin{array}{c}\text { Depletion by } \\
\text { reservoirs } \\
\text { (3) }\end{array}$ & $\begin{array}{c}\text { Subtotal } \\
\text { (4) }\end{array}$ & $\begin{array}{c}\text { In-channel } \\
\text { commitment } \\
\text { (5) }\end{array}$ & $\begin{array}{l}\text { Total } \\
(6)\end{array}$ & $\begin{array}{l}\text { Potentially } \\
\text { assured } \\
\text { (7) }\end{array}$ & $\begin{array}{c}\text { Total } \\
\text { streamflow } \\
\text { (8) }\end{array}$ \\
\hline 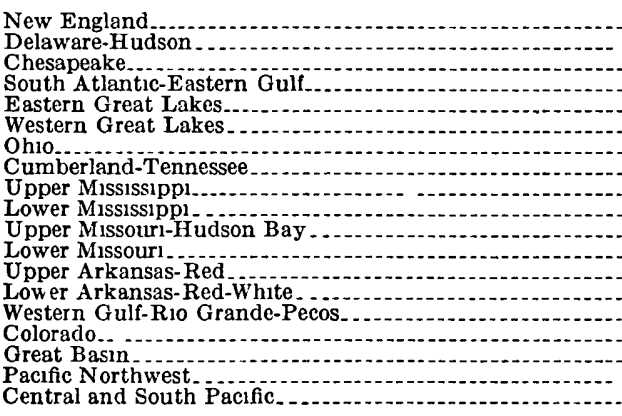 & $\begin{array}{r}0 \\
0256 \\
0548 \\
0296 \\
0430 \\
0372 \\
0469 \\
0293 \\
0149 \\
0303 \\
0598 \\
0412 \\
0277 \\
0326 \\
0328 \\
0619 \\
0564 \\
0339 \\
0600 \\
2483\end{array}$ & $\begin{array}{r}0 \\
0144 \\
0301 \\
0148 \\
0758 \\
0228 \\
0413 \\
0049 \\
0083 \\
0298 \\
1584 \\
0375 \\
0055 \\
0008 \\
0240 \\
0450 \\
0106 \\
0276 \\
0056 \\
0320\end{array}$ & $\begin{array}{r}0 \\
0134 \\
0214 \\
0018 \\
0067 \\
0110 \\
0109 \\
0041 \\
0088 \\
0079 \\
0085 \\
0078 \\
0059 \\
0074 \\
0159 \\
0081 \\
0048 \\
0059 \\
0113 \\
0147\end{array}$ & $\begin{array}{r}00534 \\
1063 \\
0562 \\
1255 \\
0710 \\
0992 \\
0383 \\
0320 \\
0680 \\
2267 \\
0865 \\
0391 \\
0482 \\
0727 \\
1150 \\
0718 \\
0674 \\
0768 \\
2950\end{array}$ & $\begin{array}{rr}0 \quad 429 \\
641 \\
488 \\
244 \\
2107 \\
572 \\
249 \\
784 \\
262 \\
1569 \\
0491 \\
417 \\
0268 \\
262 \\
0556 \\
0623 \\
0209 \\
535 \\
295\end{array}$ & $\begin{array}{r}0 \quad \mathbf{4 8 2} \\
\mathbf{7 4 8} \\
\mathbf{5 4 4} \\
370 \\
2 \mathbf{1 7 8} \\
\mathbf{6 7 1} \\
287 \\
816 \\
330 \\
1395 \\
1356 \\
456 \\
0750 \\
335 \\
1706 \\
1341 \\
0883 \\
612 \\
590\end{array}$ & $\begin{array}{c}0640 \\
556 \\
473 \\
469 \\
414 \\
362 \\
326 \\
612 \\
227 \\
368 \\
0399 \\
113 \\
0501 \\
193 \\
0752 \\
0384 \\
0339 \\
341 \\
244\end{array}$ & $\begin{array}{r}1086 \\
912 \\
769 \\
783 \\
847 \\
483 \\
777 \\
1003 \\
344 \\
811 \\
0583 \\
433 \\
0880 \\
698 \\
172 \\
0443 \\
0446 \\
610 \\
511\end{array}$ \\
\hline Mean & 0516 & 0320 & 0086 & 0922 & 271 & 363 & 210 & 388 \\
\hline
\end{tabular}

1 Land-treatment measures and wetlands only 
Table 8 and figure 3 summarize the preceding comparison.

Briefly, potential assured supply exceeds projected commitment in three regions: New England, South Atlantic-Eastern Gulf, and Ohio. Only in these three is it expectable that water requirements for the economic and social evolution projected by Wollman and Eliasburg could be realized easily. In the remaining 16 regions, projected commitments exceed assured supply as here defined.

\section{TABLE 8.-Projected water demand as of the year 2000}

[In percent of potential assured supply]

\begin{tabular}{|c|c|c|c|c|}
\hline Region & $\begin{array}{l}\text { Consumed } \\
\text { off channel }\end{array}$ & $\begin{array}{l}\text { Consumed } \\
\text { on site }\end{array}$ & $\begin{array}{l}\text { Dominant } \\
\text { in-channel } \\
\text { flow }\end{array}$ & Total \\
\hline 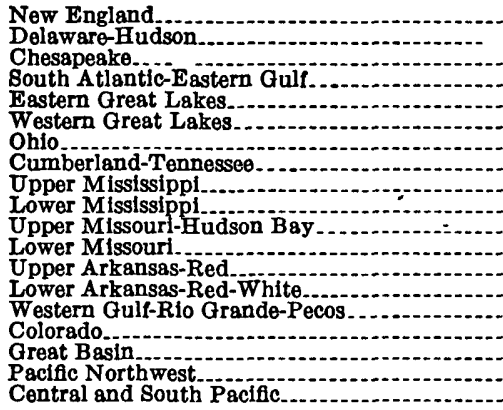 & $\begin{array}{r}4 \\
10 \\
6 \\
9 \\
9 \\
13 \\
9 \\
2 \\
13 \\
16 \\
103 \\
25 \\
65 \\
17 \\
82 \\
147 \\
100 \\
18 \\
102\end{array}$ & $\begin{array}{r}4 \\
9 \\
6 \\
18 \\
8 \\
14 \\
3 \\
3 \\
17 \\
45 \\
114 \\
10 \\
31 \\
21 \\
71 \\
40 \\
99 \\
5 \\
19\end{array}$ & $\begin{array}{r}67 \\
115 \\
103 \\
52 \\
509 \\
158 \\
76 \\
128 \\
116 \\
426 \\
123 \\
370 \\
53 \\
136 \\
74 \\
162 \\
62 \\
157 \\
121\end{array}$ & $\begin{array}{r}75 \\
134 \\
115 \\
79 \\
526 \\
185 \\
88 \\
133 \\
146 \\
487 \\
340 \\
405 \\
150 \\
174 \\
227 \\
349 \\
260 \\
180 \\
242\end{array}$ \\
\hline Mean & 25 & 19 & $12 \theta$ & 173 \\
\hline
\end{tabular}

In 7 of the 16 regions of seeming water deficiency, assured supply is greater than projected consumption (off-channel plus on-site) and total streamflow equals or exceeds total commitment. In these seven regions, therefore, most water requirements for the projected economic and social evolution can be realized if virtually complete regulation of streamflow proves feasible. The seven regions are the DelawareHudson, Chesapeake, Cumberland-Tennessee, Upper Mississippi, Upper Arkansas-Red, Lower Arkansas-Red-White, and Pacific Northwest.

In the remaining nine regions, total commitment exceeds total streamflow. Projected consumption exceeds assured supply in five of these nine, and exceeds total streamflow in three. Consequently, in these nine regions it is expectable that, even with streamflow regulated to the utmost, economic and social evolution will be handicapped moderately to severely. The nine regions in this category are the Eastern Great Lakes, Western Great Lakes, Lower Mississippi, Upper Missouri-Hudson Bay, Lower Missouri, Western Gulf-Rıo GrandePecos, Colorado, Great Basin, and Central and South Pacific. Together, the nine span 55 percent of the 48 conterminous States. 


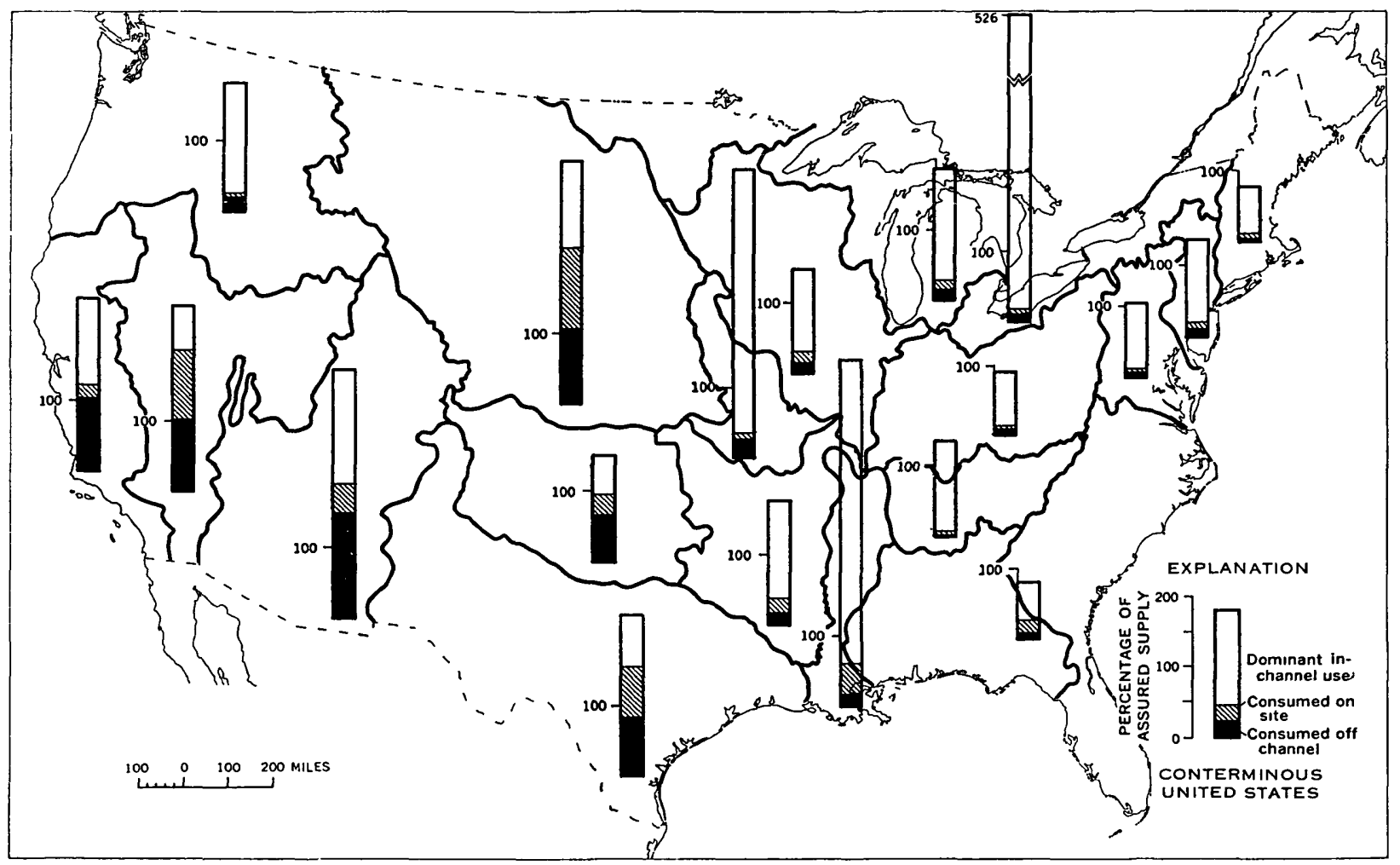

Fiodre 3 - Projected water demand as of the year 2000 The bar diagrams show, for the water-resources regions, water demand, as projected by Wollman (1960) and Ellasburg (1960), expressed a s percentage of as 


\section{COURSES OF ACTION}

Obviously, pure water is becoming a critical commodity whose abundance is about to set an upper limit of economic evolution in a few parts of the Nation and inevitably will do so rather widely within half a century or less. Prudence requires that the Nation learn to manage its water supplies boldly, imaginatively, and with utmost efficiency. Time in which to develop such competence is all too short.

As the basis for water-management decisions that seem imminently necessary, the Nation has only a bare minimum of relevant information. Water facts of all kınds, in ever wider scope and ever greater detall, will be prerequisite to sound decisions So also will plans for alternative schemes for comprehensive water control and management and for corresponding schedules of cost-in dollars, in economic opportunities created on the one hand and foreclosed on the other, and in "second-generation" problems that can be anticipated. Here the all-embracing plan, immutable for all time, rises as an enticing will-o'-the-wisp. In actuality, the process of information gathering, decision, and action will never end. Each such cycle inevitably will create the seed of an ensuing cycle, and successive cycles will deal with progressively more complex situations and will be less susceptible to "crash" procedures.

No single course of action can be a panacea for all water-supply ills. Thus, the objectives of water-supply management must be varied from one situation to another.

As one example, consider the case for desalting ocean water or other brines as a "new" source of fresh water, potentially in extremely large volume. Several effective techniques for desalting are established and are being refined. On a pllot-plant scale, the cost approaches but has not yet reached the target of $\$ 1$ per thousand gallons of fresh-water product. It is reasonable to expect that cost at point of production ultımately can be diminished to and below the target. However, considering the quantity of energy required for separating water from dissolved salts and, further, considering costs at which energy reasonably can be produced and applied to the separation, the writer considers it highly unlıkely that the overall cost of desalting ocean water can, in the foreseeable future, be duminished by an order of magnitude below the target-that is, to as little as 10 cents per thousand gallons. Actual use of desalted ocean water will involve an additional increment of cost-that of pumping from the desalting plant to the place of use against the head necessary for effective distribution.

In contrast, average costs in the United States in 1954 were about $181 / 2$ cents per thousand gallons for pure, fresh water from municipal systems, commonly as little as one-tenth that amount for industrial and 
irrigation water, and about 8 cents for treating sewage. From one place to another, the approximate range in local costs was from 50 to 200 percent of the average. These costs include operation, maintenance, and amortization of capital investment. Those for municipally supplied water and for treating sewage were derived by the writer from data by the U.S. Public Health Service (1960 and 1960a).

Thus, at current and prospective costs as cited above, fresh water obtained by desalting oceanic and other brines seems most unlikely to be universally advantageous. Desalting can, and probably will, compete economically as a source for municipal supply in areas along the immediate coast where water from streams and other conventional sources is unobtainable in adequate volume and where the salts that are removed can be returned tc the ocean at little cost. Probably it will compete also in deriving usable supplies from inland brackish waters; at inland sites, however, disposal of the removed salts may be difficult and costly. Elsewhere, "rules of the market place" dictate that the principal course of future action be concerted management of the conventional surface-water and ground-water sources, including those now submarginal in cost.

Much water must be reclaimed from industrial and municipal wastes and reused several times. For such reclaiming, desalting may prove feasible (Oltman and others, 1960). Repeated reuse will become necessary throughout the East if projected consuming uses are to be satisfied from projected in-channel flows. Reuse diminishes withdrawal at the source but does not diminish consumption. Thus, reuse will not modify the demand-supply comparisons of table 6 .

Over most of the West, except only the Pacific Northwest, projected commitment-that is, off-channel and on-site consumption plus dominant in-channel flow-exceeds assured supply. There, the obvious alternatives are either less consumption per unit of product or diminished production. There a considerable part of the commitment, even a major part, is consumption in agriculture, largely in irrigation. There, substantially diminished consumption implies improved efficiency in irrigation. Such improvement must be sought dilıgently; it will not easily be realized in a large measure.

Of on-site consumption, 68 percent of that projected for improving fish-and-wlldlife habitat occurs in four regions--South AtlanticEastern Gulf, Lower Mississippi, Upper Missouri-Hudson Bay, and Western Gulf-Rio Grande-Pecos (See table 6, column 6) Only in the first of these regions can this particular projection be realized concurrently with other projected demands, each in full. In the remaining three regions, the respective projections are 42 percent, 87 percent, and 57 percent of potential assured supply (as defined by the writer). In these three, and to a smaller degree in five additional 
regions-Western Great Lakes, Upper Mississippi, Lower ArkansasRed-White, Colorado, and Great Basin-compromise seems ultimately inevitable between an ideal habitat for fish and wildlife on the one hand and the several potentially competing demands for water on the other hand. In this connection, it is emphasized that all the habitat here considered, and covered under table 6 , is that proposed to be created by man.

By the year 2000, estimated reservoir depletion will be only 4 percent of potential assured supply (table 6, column 7). However, it would exceed 10 percent in five regions-Upper Missouri-Hudson Bay, Upper Arkansas-Red, Western Gulf-Rio Grande-Pecos, Colo$\mathrm{rado}_{\text {, }}$ and Great Basin. Particularly in these five, measures that substantially diminish evaporation would ease prospective deficiencies in water supply. Although results have been disappointing thus far, attempts to discover effective measures and materials should continue as long as there is hope for success.

Depletion by evaporation from water surfaces can, in principle, be diminished also to the extent that streamflow can be regulated in natural underground reservoirs in lieu of manmade reservoirs on the land surface. Capability of underground reservoirs for water-supply management seems potentially large. Field studies to evaluate such capability and to establish procedures are urged.

The potential for salvaging part of the water transpired by noneconomic native vegetation is in a sense analogous to suppression of evaporation from reservolrs, but differs in that a "new" water-supply component would be created. The quantity of this water is large; in the 17 Western States about $20,000 \mathrm{mgd}$ is transpired by phreatophytes, plants withdrawing water that otherwise would reach a stream (Oltman and others, 1960). Methods for eradicating phreatophytes at acceptable cost are under test, principally by the U.S. Army Corps of Engineers and the U.S. Bureau of Reclamation. Field evaluation of the eradication in terms of increased water supply is pending.

A principal concern of the future will be with in-channel flows and, in particular, with flow for diluting wastes. It appears implicit in the projections by Wollman (1960) and by Reid (1960) that nearly all wastes would be commingled with all the avallable water and that, with certain pretreatment of the wastes (p. 17), dilution could be sufficient that the misture would be usable for substanially all purposes. According to the projections in table 6, however, water for dilution would be insufficient in most regions-definitely in Western Great Lakes, Upper Arkansas-Red, Western Gulf-Rio Grande-Pecos, and Central and South $\mathbb{P a c i f i c}$ - and also to a smaller and variable degree in all other regions except the three in which assured supply exceeds projected commitment. 
Means must be found to diminish the dilution requirement. Relief will not lie in more inclusive pretreatment of wastes, because the projections already assume a very large percentage removal of BOD. Measures alternative to dilution, that can be considered where and when need arises, include the following:

1. In metropolitan areas, separate distribution of high-purity water for intake by humans and animals, and of lower purity water for industrial purposes, fire protection, sanitary flushing, and the like. Native stream and ground waters would be conserved for the high-purity system; reclaimed waters could go to the lower purity system. Currently, somewhat less than 10 percent of all water used off-channel is in municipal-supply systems that require high purity.

2. Partial or complete removal of solutes from waste fluids, in effect diluting the waste sufficiently for general reuse. Practical means for so reclaiming waste waters should be sought with some sense of urgency.

3. Waste canals or pipelines, separated from stream channels and leading to off-channel disposal areas where feasible. Part of or all the wastes might be concentrated in some degree prior to disposal or they might even be desiccated.

4. Chemical disintegration or separate disposal, or both, of industrial wastes that do not oxidize under conventional treatment. These would include toxins and "exotic" wastes from the chemical and nuclear-energy industries, wastes that presumably will be produced in ever larger quantities.

Measures such as those just outlined would be simplified if sources of the most troublesome wastes were segregated by area, preferably downbasin. Zoning of this sort has been recommended to delineate and conserve opportunities for outdoor recreation (U.S. Geological Survey, 1962). It might best be realized through the local and State police powers, coupled with conservancy commissions of local, statewide, or even regionwide jurisdiction. Regionwide jurisdictions would preforce rest on interstate negotiations. Whatever its purpose, however, zoning is distasteful; probably, therefore, it will prove to be a last-resort tool in managing water supplies.

Commonly the dominant in-channel projection is for a purpose other than dilution of wastes-for fish and wildfowl habitat, for hydroelectric power, or for navigation. Locally, it might be for recreation. Commonly, also, it exceeds assured supply-for example, the projections for hydroelectric power in the Eastern Great Lakes and Pacific Northwest regions, those for navigation in the Mississippi and Missouri River basins, and that for fish and wildfowl habitat in the Colorado River basin. (See table 6.) These and other in-channel 
projections cannot be realized in full. Inevitably, realistic compromises must be reached among off-channel consumption, on-site consumption, and the several in-channel requirements and opportunities.

All these matters concern management of water supply in the engineering sense. Beyond them are related unresolved questions in the field of administrative management. What would be the most appropriate ultimate assignment of responsibility and authority over such unlike matters as inventory of uncommitted water resources, planning and construction for river regulation, allocation of the resource among potentially competitive and mutually exclusive uses, segregation and appropriate treatment or disposal of wastes? Responsiblity and authority now rest in many agencies-municipal, State, and Federal, but commonly are either too fragmentary or too specialized to encompass all the necessary courses of action. Is there some reasonable, workable compromise between this presently fractionated concern and overall authority assigned to a single governmental colossus?

Cost of water-supply management as here outlined will be large, obviously. How can this large cost be shared equitably among the individual user and taxpayer, the private entrepreneur of commerce or industry, and the many agencies of government?

Current legal rights of the individual to water or to its exclusive use could, if unmodified or unrestrained, greatly complicate watermanagement procedures of the year 2000. Should these rights, now absolute in most States, be relaxed to the end that a common advantage may be realized from a simpler, more effective procedure? In another context, the writer has concluded that they will be so relaxed, by evolution (Piper, 1959).

The title of this paper is a general question, "Has the United States enough water?" A comprehensive answer, binding as of the year 2000 , is not possible from information at hand or in early prospect. However, this paper has served its purpose if it has broken down the general question into correlative aspects and courses of early action. Definitive answers to the numerous residual questions must be found.

\section{REFERENCES}

Douglas, E M , 1932, Boundaries, areas, geographic centers of the United States and the several States: U S. Geological Survey Bull. 817, 265 p.

Eliasberg, V. F , 1960, Regional water supply and projected uses. In Wollman, 1960 [see below]

Langbein, W. B , 1959, Water yield and reservoir storage in the United States * U S Geol. Survey Circ. 409, 5 p.

Langbein, W. B , and others, 1949, Annual runoff in the United States: U S Geol

- Survey Circ. 52, p 5.

Mackichan, K A., and Kammerer, J. C, 1961, Estimated use of water in the United States, $1960 \cdot$ U S Geol. Survey Circ. 456, 44 p., 10 fig. 
Meyers, J. S., 1962, Evaporation from the 17 Western States $\cdot$ U S Geol. Survey Prof. Paper 272-D, p. 93-95.

Oltman, R. E, and others, 1960, National water resources and problems U.S. Senate, Select Comm. on National Water Resources, 86th Cong., 2d sess., Comm. Print 3, 42 p , 43 fig

Piper, A M., 1959, Requirements of a model water law Am. Water Works Assoc. Jour., $\nabla 51 \mathrm{p}$ 1211-1216.

Re1d, G. W, 1960, Methods of approximating dilution water requirements as a supplemental measure for control of water quality in rivers: U S. Senate, Select Comm. on National Water Resources, 86th Cong., 2d sess, Comm. Print 29, 28 p.

Thomas, N. O., and Harbeck, G E, Jr, 1956, Reservoirs in the United States: U.S Geol Survey Water-Supply Paper 1360-A, 99 p, 1 pl , 3 fig

Thornthwaite, C. W., 1952, Evapotranspiration in the hydrologic cycle, in The physical and economic foundation of natural resources U S House of Reprepresentatives, Interior and Insular Affiairs Comm, v. 2, p 25-35.

U.S. Dept. Agriculture, 1960, Estımated water requirements for agricultural purposes, and their effects on water supplies U S Senate, Select Comm. on National Water Resources, 86th Cong, 2d sess, Comm. Print 13, 24 p

U S Geological Survey, 1962, Water for recreation-Values and opportunities: Outdoor Recreation Resources Review Comm. Study Rept. 10, 73 p.

U S Public Health Service, 1960, Future water requirements for municipal purposes U.S. Senate, Select Comm. on National Water Resources, 86th Cong , 2d sess , Comm. Print 7, 24 p

1960a, Pollution abatement: U.S. Senate, Select Comm on National Water Resources, 86th Cong , 2d sess , Comm Print 9, $38 \mathrm{p}$

U.S. Weather Bureau, 1959, Evaporation maps for the United States: U.S Weather Bureau Tech Paper 37

1960, in U.S. Dept Agriculture, 1960 [see above].

Wollman, Nathaniel, 1960, A preliminary report on the supply of and demand for water in the united States as estımated for 1980 and 2000. U S Senate, Select Comm. on National Water Resources, 86th Cong, 2d sess, Comm Print 32, 131 p. 